\title{
ORAL FINDINGS IN PATIENTS WITH APERT SYNDROME
}

\author{
ACHADOS BUCAIS EM PACIENTES COM SÍNDROME DE APERT
}

\author{
Gisele da Silva DALBEN¹, Lucimara Teixeira das NEVES², Marcia Ribeiro GOMIDE ${ }^{3}$
}

\author{
1- DDS, MSc, PhD student; Public Health Dentistry Sector, Hospital for Rehabilitation of Craniofacial Anomalies, University of São Paulo, \\ Bauru, SP, Brazil. \\ 2- DDS, MSc; Pediatric Dentistry Sector, Hospital for Rehabilitation of Craniofacial Anomalies, University of São Paulo, Bauru, SP, Brazil \\ 3- DDS, MSc, PhD; Pediatric Dentistry Sector, Hospital for Rehabilitation of Craniofacial Anomalies, University of São Paulo, Bauru, SP, \\ Brazil
}

Corresponding address: Gisele da Silva Dalben - Setor de Odontologia em Saúde Coletiva/HRAC-USP - Rua Silvio Marchione, 3-20 - Vila Universitária - CEP: 17012-900 - Bauru - SP - Brazil - Phone: +55 (14) 3235-8141; Fax: +55 (14) 3234-7828 - e- mail: gsdalben@usp.br

Received: November 23, 2006 - Modification: December 05, 2006 - Accepted: December 12, 2006

\begin{abstract}
$I_{1}$

Introduction: The Apert syndrome is a rare disorder of autosomal dominant inheritance caused by mutations in the FGFR2 gene at locus 10q26; patients with this syndrome present severe syndactyly, exophthalmia, ocular hypertelorism and hypoplastic midface with Class III malocclusion, besides systemic alterations. Most investigations available on the Apert syndrome address the genetic aspect or surgical management, with little emphasis on the oral aspects. Objective: to investigate the oral findings, including dental anomalies, ectopic eruption of the maxillary permanent first molars and soft tissue alterations, in subjects with Apert syndrome. Material and methods: clinical and radiographic examination of nine patients with Apert syndrome, aged 6 to 15 years, not previously submitted to orthodontic or orthognathic treatment. Results: dental anomalies were present in all patients, with one to eight anomalies per individual. The most frequent anomalies were tooth agenesis, mainly affecting maxillary canines, and enamel opacities (44.4\% for both). Ectopic eruption of maxillary first molars was found in $33.3 \%$ of patients; lateral palatal swellings were observed in $88.8 \%$ of patients. Conclusions: The occurrence of typical lateral palatal swellings agrees with the literature. The high prevalence of dental anomalies and ectopic eruption may suggest a possible etiologic relationship with the syndrome.

Uniterms: Tooth abnormalities; Mouth abnormalities; Tooth eruption, ectopic; Craniosynostoses; Acrocephalosyndactylia.
\end{abstract}

\section{RESUMO}

$I_{1}$

ntrodução: A síndrome de Apert é um distúrbio raro de herança autossômica dominante causado por mutações no lócus 10q26 do gene FGFR2; pacientes com esta síndrome apresentam sindactilia severa, exoftalmia, hiperteleorbitismo e hipoplasia da face média com má oclusão de Classe III, além de alterações sistêmicas. A maior parte dos estudos disponíveis sobre a síndrome de Apert aborda o aspecto genético ou manejo cirúrgico, com pouca ênfase nos aspectos bucais. Objetivo: investigar os achados bucais, incluindo anomalias dentárias, irrupção ectópica dos primeiros molares permanentes superiores e alterações de tecido mole, em indivíduos com síndrome de Apert. Material e métodos: exame clínico e radiográfico de nove pacientes com síndrome de Apert, de 6 a 15 anos de idade, não anteriormente submetidos a tratamento ortodôntico ou ortognático. Resultados: anomalias dentárias estavam presentes em todos os pacientes, com uma a oito anomalias por indivíduo. As anomalias mais freqüentes foram agenesia dentária, principalmente afetando os caninos superiores, e opacidades de esmalte (44,4\% para ambos). Foi observada irrupção ectópica dos primeiros molares superiores em 33,3\% dos pacientes; foram observados aumentos volumétricos laterais da mucosa palatina em $88,8 \%$ dos pacientes. Conclusões: a ocorrência de aumentos volumétricos laterais típicos da mucosa palatina concorda com a literatura. A alta prevalência de anomalias dentárias e irrupção ectópica pode sugerir uma possível relação etiológica com a síndrome.

Unitermos: Anomalias dentárias; Alterações bucais;Irrupção dentária ectópica; Craniossinostose; Acrocefalosindactilia. 


\section{INTRODUCTION}

The term craniosynostosis refers to early closure of cranial sutures; the syndromes most frequently associated with craniosynostoses are the Apert and Crouzon syndromes, besides Pfeiffer, Saethre-Chotzen, Carpenter, Jackson-Weiss and cloverleaf skull syndromes ${ }^{7}$. The treatment of craniosynostoses is essentially surgical, aiming at esthetic improvement and prevention of neurological alterations.

The Apert syndrome ${ }^{10}$ presents autosomal dominant inheritance assigned to mutations in the FGFR2 gene at locus 10q26. Patients with this syndrome present severe syndactyly of the 2nd, 3rd and 4th digits, exophthalmia, ocular hypertelorism and hypoplastic midface with Class III malocclusion and systemic alterations ${ }^{10,17}$.

Investigations reported in the literature on Apert syndrome are usually related to genetics or surgical management, with little emphasis on the oral aspects. Therefore, this study investigated the oral findings, including dental anomalies, ectopic eruption of the maxillary permanent first molars and soft tissue alterations, in a series of subjects with Apert syndrome.

\section{MATERIALS AND METHODS}

Forty-five patients with Apert syndrome are registered in the database of the Hospital for Rehabilitation of Craniofacial Anomalies, University of São Paulo (HRAC/ USP). This report includes only patients aged 6 to 15 years old.

Before onset, the study was revised and approved by the Institutional Review Board of HRAC/USP.

Children aged less than 6 years were not included because of their difficulty in complying with a radiographic examination. Besides, at this age, the tooth buds of premolars may still be absent and develop at a later stage. Individuals previously submitted to orthodontic or orthognathic treatments were also excluded, because they might have undergone serial tooth extraction, which despite the review of all patients' records could impair the diagnosis of tooth agenesis.

Some individuals had died prematurely, received definitive discharge from the hospital, abandoned treatment, and some patients did not attend the HRAC/USP during the study period. This led to this final sample of 9 patients with Apert syndrome.

A single examiner performed clinical examination of all patients. Caretakers were asked on possible previous tooth extractions or history of neonatal or natal teeth and soft tissue alterations. These data were also investigated on the patients' records.

Panoramic radiographs were obtained from all individuals. Dental anomalies were recorded by description of findings, and enamel opacities were classified according to the DDE index 5 .

\section{RESULTS}

Dental anomalies were found in all patients, with one to eight anomalies per patient. Overall, 38 tooth abnormalities were observed, being $73.6 \%$ in the maxillary arch and 78.9\% in permanent teeth. The dental anomalies observed included enamel projections, long canine cusps, supernumerary teeth, dental fusion (Figure 1), enamel opacity, enamel hypoplasia, tooth agenesis, ectopic tooth positioning (Figure 2) and tooth impaction. Enamel opacities (Figure 3) were often observed, adding up to 12 opacities in $44.4 \%$ of patients, primarily affecting permanent teeth $(66.6 \%)$, on the buccal aspect (58.3\%), of creamy-white color $(100 \%)$ and on the maxillary arch (66.6\%).

Eight permanent teeth were congenitally absent in 4 patients (44.4\%), with one to five missing teeth per patient, mainly affecting the maxillary canines (Figure 4) (50\%); maxillary lateral incisors (25\%); and mandibular canine and mandibular second premolar (12.5\% each).

Five cases of ectopic eruption of the maxillary permanent first molars were observed in 3 patients (33.3\%), being 2 bilaterally and 1 on the left side (Figure 5).

Soft tissue alterations were observed in 8 patients (88.8\%), all of which represented the typical lateral palatal swellings (Figure 6) of patients with Apert syndrome. There was no case of association with cleft palate. No further soft

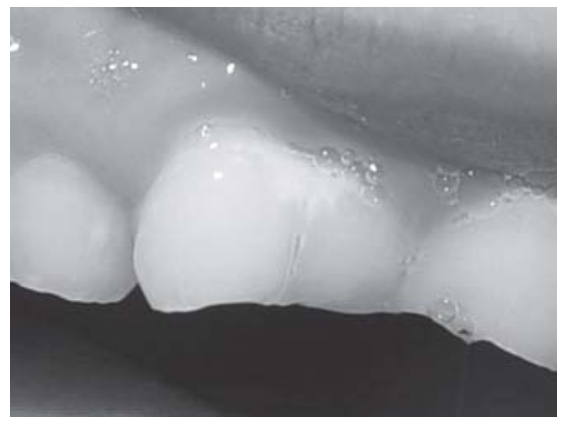

A

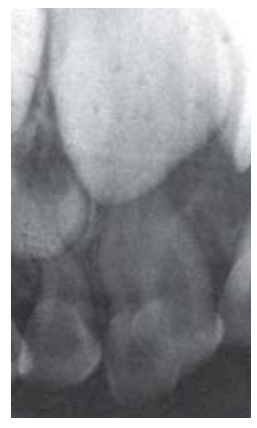

B
FIGURE 1- Dental fusion and supernumerary tooth: clinical (a) and radiographic (b) aspect

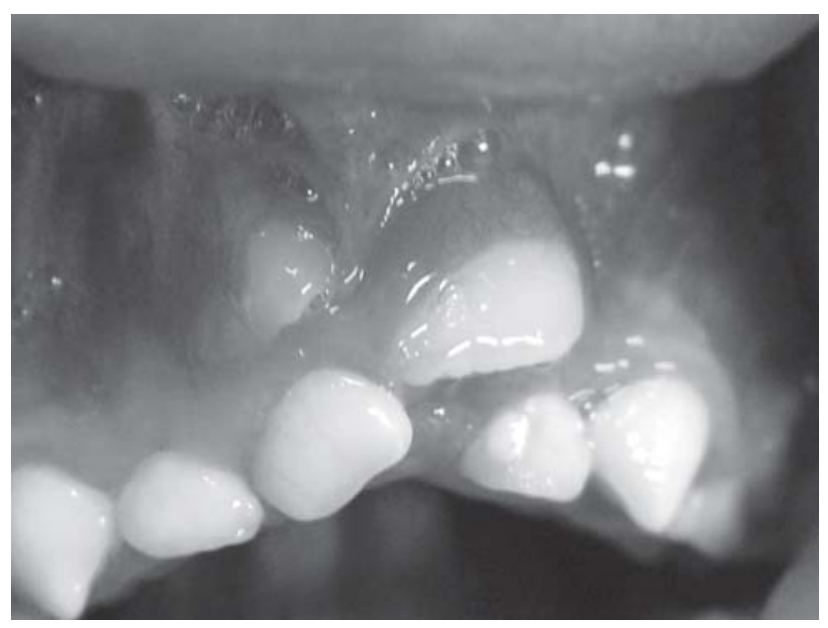

FIGURE 2- Ectopic position of the permanent maxillary central incisors 
tissue disturbances were found in any patient.

A detailed description of findings is provided in Table 1.

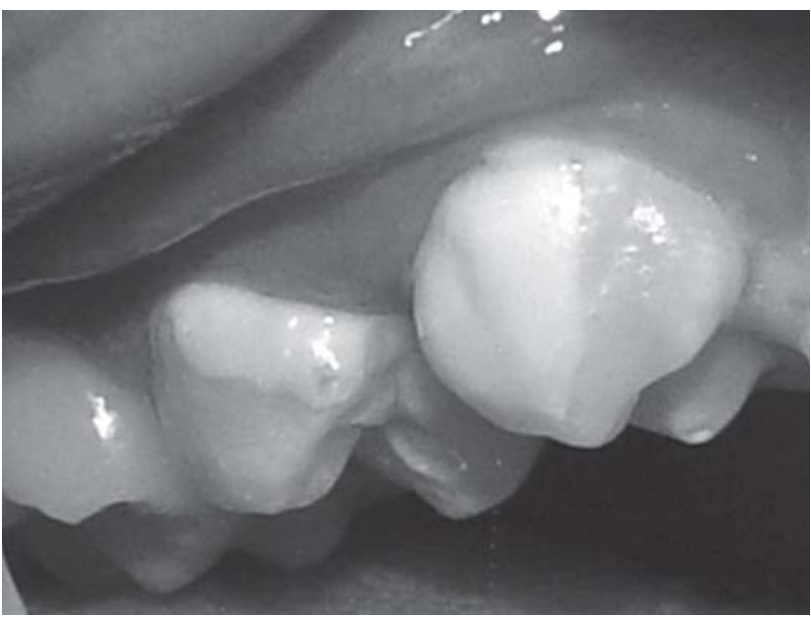

FIGURE 3- Creamy-white enamel opacities

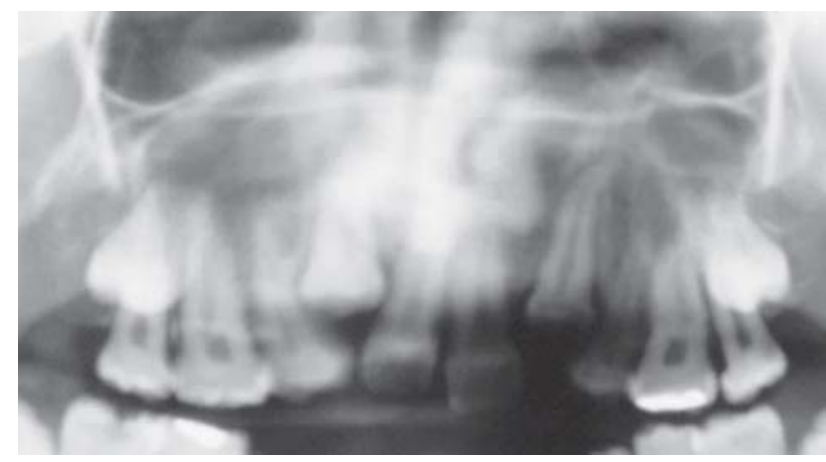

FIGURE 4- Panoramic radiograph exhibiting bilateral agenesis of the permanent maxillary lateral incisors and canines

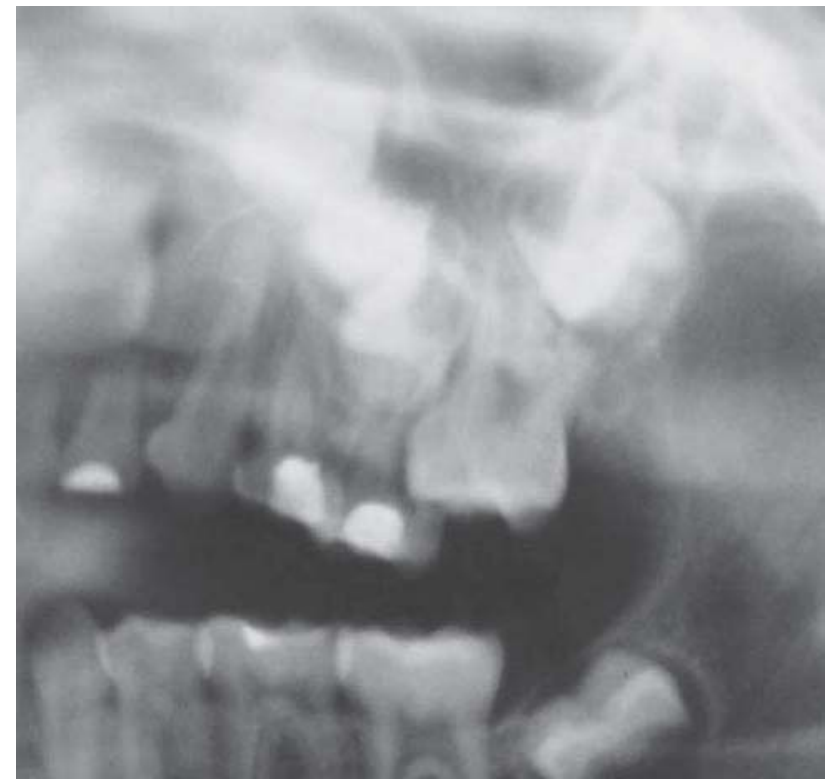

FIGURE 5- Irreversible ectopic eruption of the permanent maxillary left first molar

\section{DISCUSSION}

The observation of dental anomalies in all patients in this series and the finding of multiple anomalies in each patient may indicate a possible correlation between Apert syndrome and the occurrence of oral alterations, not described in the literature so far. Most alterations had a hypoplastic nature. The same factor causing maxillary hypoplasia in these patients might give rise to tooth agenesis or enamel hypoplasia. Tooth impaction might be secondary to maxillary hypoplasia.

The prevalence of enamel opacities (44.4\%) was higher than reported for individuals without congenital alterations, which ranges from $1.6 \%{ }^{9}$ to $9.3 \%{ }^{8}$, or for patients with cleft lip and palate $(27.9 \%)^{8}$, yet lower than that observed among premature infants and patients with congenital rubella (56.5\% and $81.8 \%$, respectively) ${ }^{8}$. In 2001, Mustafa, et al. ${ }^{11}$ observed similar prevalence of enamel opacities in patients with and without craniosynostosis, yet their sample also included patients with non-syndromic craniosynostosis. The highest frequency of affected permanent teeth in the present study may have been influenced by the higher number of erupted permanent teeth (118 permanent compared to 72 deciduous teeth).

The prevalence of tooth agenesis (44.4\%) was higher than reported for individuals without syndromes (range $2.7 \%$ to $6.9 \%)^{4,12,15}$. The predominance of agenesis of maxillary canines (50\%) and a mandibular canine (12.5\%) was surprising, since these teeth are usually stable in the general population, accounting for only $1 \%$ to $6.2 \%$ of all cases of tooth agenesis ${ }^{4,12}$. This may indicate a possible characteristic of Apert syndrome not described in the literature so far. However, further studies on larger samples are required to confirm such data. The other cases of tooth agenesis, namely maxillary lateral incisors and mandibular second premolar, agree with reports for the general population ${ }^{4,12,15}$.

The prevalence of ectopic eruption of permanent maxillary first molars (33.3\%) was high when compared to patients without congenital alterations (range $0.75 \%$ to $4.3 \%)^{2,3}$ or individuals with cleft lip and palate (15.4\% to $19.6 \%)^{1,13}$, being slightly lower than observed among patients with isolated cleft palate (20.6\% to $28.8 \%)^{1,13,14}$. This alteration

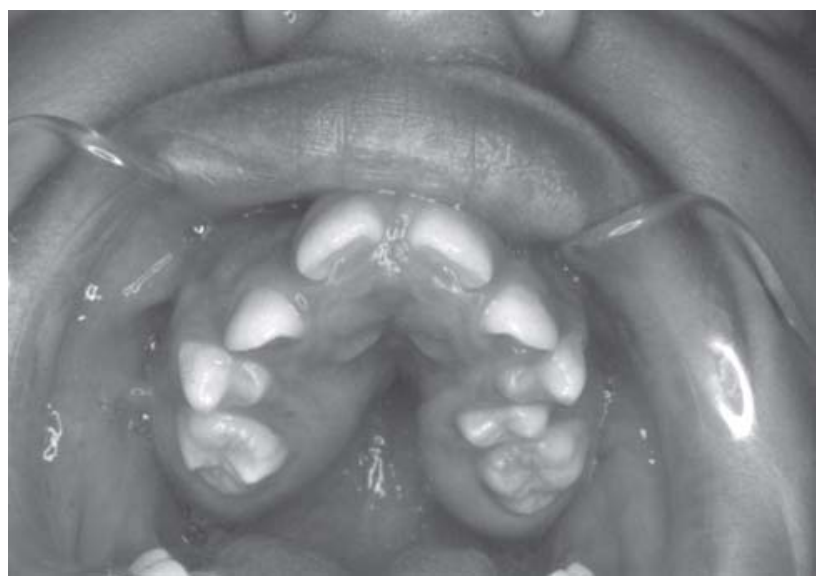

FIGURE 6- Lateral palatal swellings 
TABLE 1

\begin{tabular}{|c|c|c|c|c|c|c|c|c|c|}
\hline Patient & $\begin{array}{l}\text { Number of } \\
\text { anomalies }\end{array}$ & & & & & & & & \\
\hline 1 & 8 & $\begin{array}{l}\text { CW opacity on } \\
\text { the buccal and } \\
\text { distal aspects } \\
\text { of RMx1stPM }\end{array}$ & $\begin{array}{l}\text { CW opacity } \\
\text { on the buccal } \\
\text { aspect of } \\
\text { Rmx2ndPM }\end{array}$ & $\begin{array}{l}\text { enamel } \\
\text { hypoplasia } \\
\text { on the } \\
\text { lingual } \\
\text { aspect of } \\
\text { LMx1stPM }\end{array}$ & $\begin{array}{l}\text { CW opacity } \\
\text { on the } \\
\text { lingual } \\
\text { aspect of } \\
\text { LMx1stPM }\end{array}$ & $\begin{array}{l}\text { enamel } \\
\text { projection } \\
\text { on the } \\
\text { buccal } \\
\text { aspect of } \\
\text { LMx1stPM }\end{array}$ & $\begin{array}{l}\text { enamel } \\
\text { projection } \\
\text { on the } \\
\text { buccal } \\
\text { aspect of } \\
\text { LMx2ndPM }\end{array}$ & $\begin{array}{l}\text { impaction } \\
\text { of RMxC }\end{array}$ & $\begin{array}{l}\text { ectopic } \\
\text { position } \\
\text { of LMxC }\end{array}$ \\
\hline 3 & 7 & $\begin{array}{l}\text { brownish } \\
\text { hypoplasia } \\
\text { on the } \\
\text { buccal } \\
\text { aspect of } \\
\mathrm{LMxCl}\end{array}$ & $\begin{array}{l}\text { CW opacity } \\
\text { on the buccal } \\
\text { aspect of } \\
\text { LMdCl }\end{array}$ & $\begin{array}{l}\text { CW opacity } \\
\text { on the } \\
\text { buccal } \\
\text { aspect of } \\
\text { RMdCl }\end{array}$ & $\begin{array}{l}\text { CW opacity } \\
\text { on the } \\
\text { buccal } \\
\text { aspect of } \\
\text { deciduous } \\
\text { LMd2ndM }\end{array}$ & $\begin{array}{l}\text { CW opacity } \\
\text { on the } \\
\text { buccal } \\
\text { aspect of } \\
\text { deciduous } \\
\text { RMd2ndM }\end{array}$ & $\begin{array}{l}\text { enamel } \\
\text { hypoplasia } \\
\text { on the } \\
\text { distobuccal } \\
\text { groove of } \\
\text { deciduous } \\
\text { LMd2ndM }\end{array}$ & $\begin{array}{l}\text { agenesis } \\
\text { of LMxC }\end{array}$ & \\
\hline 4 & 5 & $\begin{array}{l}\text { fusion } \\
\text { between } \\
\text { deciduous } \\
\mathrm{RMxCl} \text { and } \\
\text { supernumerary } \\
\text { tooth }\end{array}$ & $\begin{array}{l}\text { shape } \\
\text { alteration - } \\
\text { longer cusp } \\
\text { of deciduous } \\
\text { RMxC }\end{array}$ & $\begin{array}{l}\text { shape } \\
\text { alteration - } \\
\text { longer cusp } \\
\text { of deciduous } \\
\text { LMxC }\end{array}$ & $\begin{array}{l}\text { impaction } \\
\text { of } \mathrm{LMdCl} \\
\text { at the } \\
\text { midline }\end{array}$ & $\begin{array}{l}\text { agenesis of } \\
\text { RMd2ndPM }\end{array}$ & & & \\
\hline 5 & 5 & $\begin{array}{l}\text { CW opacity } \\
\text { on the lingual } \\
\text { aspect of } \\
\text { deciduous } \\
\text { RMx1stM }\end{array}$ & $\begin{array}{l}\text { shape } \\
\text { alteration - } \\
\text { longer cusp } \\
\text { of deciduous } \\
\text { RMxC }\end{array}$ & $\begin{array}{l}\text { ectopic } \\
\text { eruption of } \\
\text { RMx1stM }\end{array}$ & $\begin{array}{l}\text { ectopic } \\
\text { eruption of } \\
\text { LM×1stM }\end{array}$ & $\begin{array}{l}\text { supernumerary } \\
\text { tooth at the } \\
\text { area between } \\
\mathrm{LMxCl} \text { and } \\
\mathrm{LMxC}\end{array}$ & & & \\
\hline 6 & 5 & $\begin{array}{l}\text { agenesis of } \\
\text { RMxLI }\end{array}$ & $\begin{array}{l}\text { agenesis of } \\
\mathrm{RM} \times \mathrm{C}\end{array}$ & $\begin{array}{l}\text { agenesis of } \\
L M \times L I\end{array}$ & $\begin{array}{l}\text { agenesis of } \\
\text { LMXC }\end{array}$ & $\begin{array}{l}\text { agenesis of } \\
\text { RMdC }\end{array}$ & & & \\
\hline 7 & 3 & $\begin{array}{l}\text { CW opacity } \\
\text { on the lingual } \\
\text { aspect of } \\
\text { RMx1stPM }\end{array}$ & $\begin{array}{l}\text { CW opacity } \\
\text { on the cusp } \\
\text { tips of } \\
\text { LMx1stPM }\end{array}$ & $\begin{array}{l}\text { agenesis of } \\
\mathrm{RM} \times \mathrm{C}\end{array}$ & & & & & \\
\hline 8 & 2 & $\begin{array}{l}\text { ectopic } \\
\text { eruption of } \\
\text { RMx1stM }\end{array}$ & $\begin{array}{l}\text { ectopic } \\
\text { eruption of } \\
\text { LMx1stM }\end{array}$ & & & & & & \\
\hline 9 & 2 & $\begin{array}{l}\text { enamel } \\
\text { projection } \\
\text { on the } \\
\text { mesial } \\
\text { aspect of } \\
\text { LMd1stPM }\end{array}$ & $\begin{array}{l}\text { enamel } \\
\text { projection } \\
\text { on the } \\
\text { mesial } \\
\text { aspect of } \\
\text { RMd1stPM }\end{array}$ & & & & & & \\
\hline 2 & 1 & $\begin{array}{l}\text { ectopic } \\
\text { eruption of } \\
\text { LM×1stM }\end{array}$ & & & & & & & \\
\hline
\end{tabular}

R: right, L: left, W: white, CW: creamy-white, Mx: maxillary, Md: mandibular, Cl: central incisor, LI: lateral incisor, C: canine, 1stPM: first premolar, 2ndPM: second premolar, 1stM: first molar, 2ndM: second molar 
can be related to maxillary hypoplasia, which may lead to lack of space and consequently to eruption disturbances.

The presence of lateral palatal swellings in $88.8 \%$ of the sample is concordant with similar reports; the lack of association with cleft palate is in agreement with the literature, which assigns such reports to mistaken diagnoses due to the aspect caused by the lateral palatal swellings ${ }^{10,17}$. The typical palatal morphology of these patients is related to the maxillary hypoplasia observed in this syndrome. This hypoplasia leads to compression of the dental arch, which then becomes $\mathrm{V}$-shaped, giving rise to irregular tooth positioning and thickening of the alveolar ridge. This process is partially responsible for the typical palatal morphology, but there is also hyperplasia of the palatal mucosa, which increases with age. This hyperplasia is formed by soft tissue and is primarily composed of deposits of acid mucopolysaccharides (MPS), not found in biopsies of other structures of these patients, as skin or organs. These MPS deposits are rare in other palatal alterations not related to Apert syndrome ${ }^{16}$. Ferraro ${ }^{6}$ (1991) reported that these lateral palatal swellings might lead to food impaction in the central groove in the palate.

Considering this high rate of oral alterations, patients with Apert syndrome may have large dental needs; thus, dental professionals should be well informed on the oral aspects of these individuals, to be able to provide thorough information to patients and parents. Knowledge on the oral disturbances present in this syndrome is fundamental to establish a treatment plan adequate to their needs.

\section{CONCLUSIONS}

The frequent occurrence of dental anomalies, ectopic eruption and soft tissue alterations observed in this series of patients with Apert syndrome suggests a possible relationship between these disturbances and the syndrome.

\section{REFERENCES}

1- Bjerklin K, Kurol J, Paulin G. Ectopic eruption of the maxillary first permanent molars in children with cleft lip and/or palate. Eur J Orthod. 1993;15(6):535-40.

2- Bjerklin K, Kurol J. Prevalence of ectopic eruption of the maxillary first permanent molar. Swed Dent J. 1981;5(1):29-34.

3- Chintakanon K, Boonpinon P. Ectopic eruption of the first permanent molars: prevalence and etiologic factors. Angle Orthod. 1998;68(2):153-60.

4- Davis PJ. Hypodontia and hyperdontia of permanent teeth in Hong Kong schoolchidren. Community Dent Oral Epidemiol. 1987;15(4):218-20.

5- A review of the developmental defects of enamel index (DDE Index). Commission on Oral Health, Research \& Epidemiology. Report of an FDI Working Group. Int Dent J. 1992;42(6):411-26.

6- Ferraro NF. Dental, orthodontic and oral/maxillofacial evaluation and treatment in Apert syndrome. Clin Plast Surg. 1991;18(2):291307.
7- Gorlin RJ, Cohen MM Jr, Levin LS. Syndromes with craniosynostosis: general aspects and well-known syndromes. In: Gorlin RJ, Cohen Junior MM, Levin LS, editors. Syndromes of the head and neck. New York: Oxford: University Press; 1990. p. 51939.

8- Hall RK. Prevalence of developmental defects of tooth enamel (DDE) in a pediatric hospital department of dentistry population (I). Adv Dent Res. 1989;3(2):114-9.

9- Li Y, Navia JM, Bian JY. Prevalence and distribution of developmental enamel defects in primary dentition of Chinese children 3-5 years old. Community Dent Oral Epidemiol. 1995;23(2):72-9.

10- McKusick VA. Apert syndrome. Available at Acess: http:// www.ncbi.nlm.nih.gov/entrez/dispomim.cgi?id=101200. Online Mendelian Inheritance in Man. Monday, Jan. 23, 2006.

11 - Mustafa D, Lucas VS, Junod P, Evans R, Mason C, Roberts GJ. The dental health and caries-related microflora in children with craniosynostosis. Cleft Palate Craniofac J. 2001;38(6):629-35.

12- Nordgarden H, Jensen JL, Storhaug K. Reported prevalence of congenitally missing teeth in two Norwegian counties. Community Dent Health. 2002;19(4):258-61.

13- Silva Filho OG, Albuquerque MVP, Costa B. Erupción ectópica del primer molar superior permanente en pacientes portadores de labio leporino y paladar hendido. Rev Española Ortod. 1990;20(2):15565.

14- Silva Filho OG, Albuquerque MVP, Costa B. Irrupção ectópica do primeiro molar permanente superior em pacientes portadores de fissura isolada de palato (fissura pós-forame incisivo). Rev Odontol Univ São Paulo. 1993;7(1):1-10.

15- Silva Meza R. Radiographic assessment of congenitally missing teeth in orthodontic patients. Int J Paediatr Dent. 2003;13(2):1126.

16- Solomon LM, Medenica M, Pruzansky S, Kreiborg S. Apert syndrome and palatal mucopolysaccharides. Teratology. 1973;8(3):287-92.

17- Zanini SA. Apert, Crouzon e Pfeiffer. In: Zanini SA, editor. Cirurgia craniofacial: malformações. Rio de Janeiro: Revinter; 2000. p. 26976 